\title{
THE EFFECT OF GENOTYPE ON RESPONSE IN BODY COMPOSITION TO VARIATION IN DIETARY PROTEIN : ENERGY RATIOS
}

\author{
B. Indarsih ${ }^{1}$ and R. A. E. Pym ${ }^{2}$ \\ ${ }^{1}$ Department of Animal Production, Faculty of Animal Science, University of Mataram, \\ Jl. Majapahit No. 62 Mataram, 83125. NTB, Indonesia \\ ${ }^{2}$ Department of Farm Animal Medicine and Production \\ School of Veterinary Science, University of Queensland, St. Lucia, Australia \\ Corresponding E-mail:budiindarsih@gmail.com \\ Received January 14, 2010; Accepted May 22, 2010
}

\begin{abstract}
An experiment with 480 day-old chicks of four commercial strains was conducted to study the effect of genotype on response in body composition to variation in dietary protein: energy ratios. The chicks were randomly allocated into $4 \times 2 \times 4$ factorial and fed on a commercial starter diet $(250 \mathrm{~g} \mathrm{CP}$ and $12.5 \mathrm{MJ}$ of $\mathrm{ME} / \mathrm{kg}$ ) from hatching to $5 \mathrm{~d}$ of age and divided into two groups with three replications each of 16 birds and given either the such starter diet (S) or a finisher diet (F) containing $190 \mathrm{~g} \mathrm{CP}$ and 13.0 MJ of ME $/ \mathrm{kg}$. The birds were reared in strain-and sex-intermingled groups in brooders and followon cages until they reached the target body weight of 600-650 g (females) or 650-700 g (males) and transferred to single cages and fed S or F diet until 1200-1300 g (females) or 1300-1400 g (males). The lighting program was $23 \mathrm{~h}$ light for the first two days, and reduced to $18 \mathrm{~h} / \mathrm{d}$ for the remainder of the experiment. There were considerable variations in relative growth performance, FCR, carcass fat and abdominal fat due to genotypes and dietary regimen. Although birds tend to response in similar way when dealing with the excesses and insufficient supply, the nutrient requirements in relation to the protein: energy ratios should be designed according to genetic background. The accumulation of fat during the growing period was primarily due to the genetic variation whereas beyond this age, variation in abdominal fat was due principally to dietary effects.
\end{abstract}

Keywords: growth, starter, finisher, strain, broiler

\section{INTRODUCTION}

Genetic variation contributes approximately $40 \%$ to the differences between genotypes in weight gain: feed ratio. Differences in body weight do not necessarily reflect differences in feed efficiency (Wasburn et al., 1975). This was because of different capacities to deposit fat and different capacities to metabolize energy intake (Jórgensen et al., 1990). Differences between strains in dietary protein utilization are responsible for different amino acid requirements (Leclercq, 1983). However, much of the work in determining nutrient allowance for broilers (eg. ARC, 1975; NRC, 1987; 1994) has assumed that genotype differences are small.

Although it is generally accepted that growth and body composition of broilers are influenced by the dietary protein and energy ratios (Summers et al., 1992; Corzo et al., 2005; Sadeghi and Tabiedian, 2005; Sterling et al., 2003; 2006; Rahimi and Hassanzadeh, 2007), the response of broilers to diets varying in energy: protein ratio is also dependent on the genotypes (Gous et al., 1990; Morel et al., 2002; Corzo et al., 2005; Sterling et al., 2006). Smith et al. (1998) reported on the effect of genotype and protein level on body composition in a study with two strains. The degree of response varied between the two strains; increasing dietary protein improved performance more for one strain than the other.

The conventional feeding practise applied in commercial broiler production with change from high-protein starter to lower protein grower and finisher diets normally two to three times during the growing period may not necessarily optimise performance. In studies of the effect of the time of change from starter to grower and grower to finisher diets showed a substantial effect of the time at which the finisher diets commenced. Body weight was significantly depressed while abdominal fat increased by $0.3 \mathrm{~g} / \mathrm{kg}$ for each additional day the finisher diet was fed (Saleh $e t$ 
al., 1997a; Saleh et al., 1997b). Insufficient supply of amino acids in the finisher diet was considered to be an important contributing factor to be the lower performance. This could be a major cause of observed differences in growth performance and of differences in body composition in commercial broiler production practise. Therefore, the present study is desirable to identify the response of different genotypes to variation in dietary protein: energy and to evaluate how dietary manipulation should be implemented at appropriate levels to allow the birds to perform to its genetic potential.

\section{MATERIALS AND METHODS}

\section{Animal and management}

A total of 480 day-old chicks commercial broilers (Steggels $=\mathrm{A} ; \mathrm{Cobb}=\mathrm{B}$; Ingham $=\mathrm{C}$ and Barter $=\mathrm{D})$ were obtained on the same day and sexed $(n=120$ per genotype). They were wingbanded and kept in strain-and sex-intermingled groups in a hot brooder room with the ambient temperature reduced from $31^{\circ} \mathrm{C}$ by $0.5^{\circ} \mathrm{C}$ per day until it reached $25^{\circ} \mathrm{C}$ at 12 days after which it was held at this level. The birds were fed on a commercial starter diet (S) containing $250 \mathrm{~g}$ crude protein $(\mathrm{CP})$ and $12.5 \mathrm{MJ}$ of $\mathrm{ME} / \mathrm{kg}$ from hatching to five $\mathrm{d}$ of age when they were divided into two groups of experimental diets until reached the target body weight (600 to $650 \mathrm{~g}$ for females or 650 to $700 \mathrm{~g}$ for males).

They were then transferred to single cages measuring $200 \mathrm{~mm}$ wide and $400 \mathrm{~mm}$ deep x 400 $\mathrm{mm}$ high with individual feeders in a fanventilated and temperature controlled room. Feed and water were provided ad libitum. The lighting program was $23 \mathrm{~h}$ light for the first two days, and reduced to $18 \mathrm{~h} / \mathrm{d}$ for the remainder of the experiment.

\section{Experimental design}

Experiment was a factorial design. Four genotypes, two initial and two final feeding treatments and two sexes were imposed in this study. At $5 \mathrm{~d}$ of age, the birds were divided into two groups with three replications each 16 birds (96 birds/ genotype) and fed either the starter diet or a commercial broiler finisher $(\mathrm{F})$ containing $190 \mathrm{~g} \mathrm{CP}$ and 13.0 MJ of ME/kg until achieved the target body weight.

As each strain $\mathrm{x}$ sex $\mathrm{x}$ feeding treatment reached the nominated target body weight, 16 birds were transferred to individual growing cages and given the starter or finisher diet ad libitum. In these individual cages, the birds were grown until they reached approximately 1200-1300 $\mathrm{g}$ for females and 1300-1400 $\mathrm{g}$ for males (double weight). The experimental treatments were four genotypes $\mathrm{x}$ sexes $\mathrm{x}$ two initial and two final feeding and 8 individual bird replicates. This target body weight was considered to be adequate for them to express differences in terms of both growth and body composition to dietary manipulation. Birds which reached the target body weight, feed was weighed and body weight gain (BWG) and feed conversion ratio (FCR) calculated.

After being fasted overnight, the birds were killed by cervical dislocation. Abdominal fat was removed and weighted. Abdominal fat was defined as the adipose tissue present around the vent, the bursa, and the adjacent abdominal muscles, as described by Smith (1993). The carcass was stored at $-20^{\circ} \mathrm{C}$ and analysed using Soxlet extraction method. In determining the effects of the starter treatment on body composition, two birds per sample were taken when they were transferred to the single cages.

The determined crude protein and amino acid concentrations for both starter and finisher diets are shown in Table 1.

\section{Data analysis}

Data were analysed by the GLM procedure of SAS software (Version 6.12, 1996). The major independent variables were strain, sex and diet. Least Significant Difference (LSD) multiple range tests (probability $\mathrm{P}<0.05$ ) identified all results showing a significant difference (Kaps and Lamberson, 2004)

\section{RESULTS AND DISCUSSION}

Results of the present study are given in Table 2 to 4 . The response of the four strains to dietary level of crude protein and energy revealed that a significant difference due to genotype was evident. Growth rate during the starter phase was significantly higher in the birds receiving the starter diet $(250 \mathrm{~g} / \mathrm{kg} \quad \mathrm{CP})$ than in their counterparts given the finisher diet $(190 \mathrm{~g} / \mathrm{kg} \mathrm{CP})$. There was also an indication that growth rate was more depressed in strain Ingham from 24.0 to $18.7 \mathrm{~g} / \mathrm{d}$ than Steggels, Barter and Cobb from 23.5 to $19.0,22.4$ to 18.4 and 23 to $19.4 \mathrm{~g} / \mathrm{d}$, respectively when they were fed on the starter diet than on finisher diet (Table 2). In other words, 
Table 1. Analysis of Experimental Diets Used

\begin{tabular}{lcc}
\hline Nutrient & Starter & Finisher \\
\hline Crude Protein & 230 & 190 \\
Lysine & 16.83 & 8.58 \\
Methionine & 6.76 & 4.25 \\
Methionine plus & 10.54 & 6.9 \\
cystine & & \\
Isoleucine & 9.95 & 5.43 \\
Leucine & 20.67 & 12.59 \\
Threonine & 10.65 & 5.8 \\
Tryptophan & 4.33 & 2.63 \\
Histidine & 7.54 & 4.32 \\
Valine & 10.42 & 6.93 \\
\hline
\end{tabular}

Expressed as $\mathrm{g} / \mathrm{kg}$ on as is basic (approx. $900 \mathrm{~g} / \mathrm{kg}$

Dry Matter)

Cobb was less responsive in low amino acid provided by the finisher diet. This finding may indicate that one genotype required more supply amino acids which are critical for muscle development than one other during their growing period. In agreement with Sterling et al. (2006), two genotypes responded differently and required different amino acids particularly lysine. Data provided by these authors showed that Cobb grew faster and higher feed consumption and had a better FCR than Ross 308. The lower FCR and higher BWG at the lowest lysine levels suggested that $\mathrm{Cobb}$ required less lysine.

Data obtained by Vieira et al. (2004) revealed the concept of ideal protein for growing broilers of different genotypes. Ross 308 should be provided $0.76 \%$ TDF SAA (True Digestible Faecal Sulfur Amino Acid) at adequate dietary protein level $(205 \mathrm{~g} / \mathrm{kg})$ or $1.06 \%$ TDF SAA with the high protein diet $(260 \mathrm{~g} / \mathrm{kg})$. However, as differences at placement and the beginning of the experiment, Vieira et al. (2004) limited the estimation of differences due to genotypes. Regardless of this, they have established optimum amino acid level and dietary protein level.

When considering the commercial diets used in the present study with nutrient composition as presented in Table 1, and compared to NRC (1994) recommendation for starter period (7-21 d) and growing period (21-42 d) reported by Sadeghi and Tabiedian (2005), it is necessary to revaluate the amino acid content in this commercial diets in relation to dietary protein. As a comparison, lysine content in the starter and finisher diets used in this study was $16.8 \mathrm{~g} / \mathrm{kg}$ with $250 \mathrm{CP} / \mathrm{kg}$ and $8.58 \mathrm{~g} / \mathrm{kg}$ with $190 \mathrm{~g} \mathrm{CP} / \mathrm{kg}$, respectively, which was higher in the starter but lower in the finisher diets than NRC $(12.2 \mathrm{~g} / \mathrm{kg}$ lysine with $211 \mathrm{~g}$ $\mathrm{CP} / \mathrm{kg}$ and $10.4 \mathrm{~g} / \mathrm{kg}$ lysine with $18.18 \mathrm{~g} \mathrm{CP} / \mathrm{kg}$ ). Although this present study is not exclusively intended to evaluate the commercial diets, understanding the differences in genotypes and use a simple approach through feeding strategies would minimise low performance if this exist. Thus, Corzo et al. (2005) studied the effect of dietary amino acid density on growth and carcass of three different broilers genotypes (two multipurpose strains and one high yield strain). High amino acid density diets improved body weight and FCR consistently measured at 14, 28, 42 and $52 \mathrm{~d}$ of age compared to the low amino acid density diet. However, not all strains responded similarly. High yield strain had lower BW and higher FCR in all periods than the two strains. Strain results for live performance were

Table 2. The Influence of the Starter or Finisher Diet during the Starter Phase from 5 Days to 600-650 g (Females) and 6 50-700 g (Males) on Grow th Rate (g/d) and Carcas s Fat $(\mathrm{g} / \mathrm{kg})$ of the Four Commercial Strains.

\begin{tabular}{lcccccc}
\hline \multirow{2}{*}{ Strain } & \multicolumn{3}{c}{$\begin{array}{c}\text { Grow th Rate* } \\
\text { Diet }\end{array}$} & \multicolumn{3}{c}{ Carcass Fat* } \\
Diet \\
\hline Steggels & Starter & Finisher & Mean & Starter & Finisher & Mean \\
Cobb & $23.5^{\mathrm{ab}}$ & 19 & 21.3 & $97^{\mathrm{a}}$ & $95^{\mathrm{b}}$ & $96.0^{\mathrm{ab}}$ \\
Ingham & $23.0^{\mathrm{ab}}$ & 19.4 & 21.2 & $105^{\mathrm{a}}$ & $112^{\mathrm{a}}$ & $108.5^{\mathrm{a}}$ \\
Barter & $24.0^{\mathrm{a}}$ & 18.7 & 21.4 & $70^{\mathrm{b}}$ & $114^{\mathrm{a}}$ & $92.0^{\mathrm{b}}$ \\
LSD 0.05 & $22.4^{\mathrm{b}}$ & 18.4 & 20.4 & $99^{\mathrm{a}}$ & $109^{\mathrm{ab}}$ & $104.0^{\mathrm{ab}}$ \\
\hline
\end{tabular}

* Sex average values for each dietary treatment

Means followed by different letters in the column are significantly different $(\mathrm{P}<0.05)$. 
influenced, to some extent, by sex and diet type, but mostly at early ages. Observed interaction at 14 and $28 \mathrm{~d}$ of age were not repeated at later ages. It means that growth rate during early age is critical for birds to express their genetic potential which depends on dietary amino acid level and ultimately determine the subsequent production performance .

Growth rate during the grower and combined phase (5 d to 1250- $1350 \mathrm{~g}$ ) (Table 4) was influenced by sex and diet, not strain whereas FCR was affected by strain and diet, but abdominal fat was responsive to all independent variables. Birds receiving the SF diets did not achieve the performance level as observed for the FS. The growth rate and FCR of FS feeding regimen considerably improved, showing 1.8 and 1.7 higher for growth rate and FCR or, almost double of the SF as the opposite combination (Table 3 and 4) but at the expense of the body composition. These revealed on how birds tried to compensate the poor growth rate under limit condition and demonstrate growth variation due to dietary regimen. These results are similar to the observations of Koch et al. (2002) who found birds with the $100 \%$-starter diets and $120 \%$ grower diet did not perform the $120 \%$ starter and $100 \%$ grower and a high performance potential genotype needs optimal diets which referred to ideal protein concepts. Amino acid supply particularly during the early life affects the subsequent performance and can not be compensated in the later phases.

In attempt to offer an idea the length of rearing period due to different dietary treatments with resulted in substantial growth rate, age at termination or at slaughter weight was $30 \pm 2.2$; $35,5 \pm 2.7 ; 36,6 \pm 2.9$ and $38.6 \pm 2.3 \mathrm{~d}$ of age for SS, SF, FS and FF. Whilst rearing period due to genotype was $37.8 \pm 2.3,37.3 \pm 2.8,37.1 \pm 2.4$ and $38.7 \pm 2.8 \mathrm{~d}$ of age for Steggels, Cobb, Ingham and Barter respectively. Combining the relative growth variation as shown in Table 3 with some consequences on other performance, in relation to differences in age at termination, the different growth responses were due to differences in voluntary feed intake (Baker, 2004). In low dietary protein, feed intake was affected by amino acid balance (Swatson et al., 2002) and unbalanced amino acid pattern in low protein diet stimulates gluconeogenesis pathway and as a consequence, fat was deposit as a result of extra calorie (Baker, 2004; Sadeghi and Tabiedian, 2005). Significant interaction strain and diet were observed of growth rate during the grower phase (Table 4), indicating the sensitiveness of growth rate due to changes in dietary crude protein : energy ratios and due to the genotype.

When considering the low FCR over the grower phase in the FS group which also demonstrated relatively high abdominal fatness (Table 4) is contrary to expectations based on the high energetic cost of depositing fatty tissues (Pym and Farrell, 1977). The apparent abnormality can be explained by the much higher growth rate during this phase of the chicks than those given the SF as a standard feeding regimen. The higher growth rate and hence much reduced maintenance cost, more than compensated for the increase in fat deposition.

In regard to the effect of dietary protein on fat accumulation, this study observed a significant reduction in abdominal fat deposition performed by birds on the SS or SF diets and an increase in birds on the FS or FF in all strains although the degree of response varied between strains (Figure 1 and Table 4). Abdominal fat of Ingham was only $62 \%, 73 \%$ and $67 \%$ respectively of Cobb, Steggels and Barter during the grower phase. However, Ingham was fatter when given the finisher diet $(114 \mathrm{~g} / \mathrm{kg})$ than given the starter $(70$ $\mathrm{g} / \mathrm{kg}$ ) during the starter period (Table 2). This shows that responses of broilers of different genetic backgrounds to a range of dietary energy: protein ratios were dependent on the age at which such diet was introduced. Feeding behaviour in response to dietary nutrient composition determined the ultimate outcome in terms of effects on growth, efficiency or carcass composition as modified by genotype (Sizemore and Siegel, 1993). In other words, both genetic strain and feeding treatment affected how the

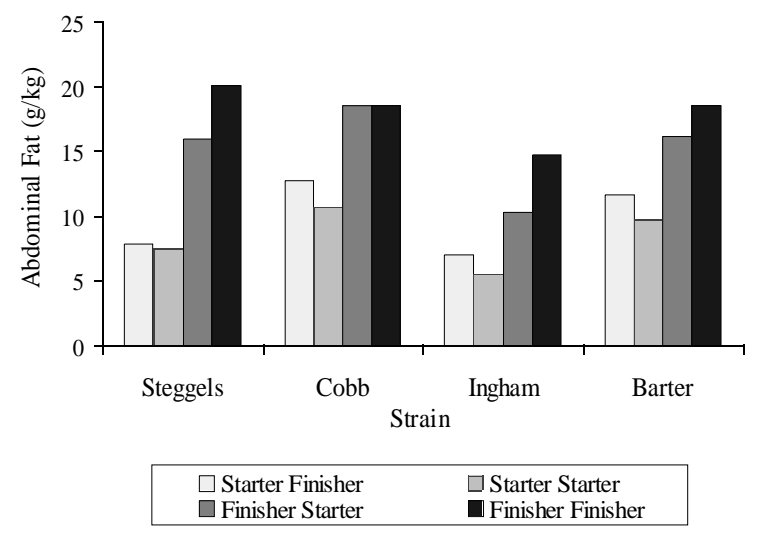

Figure 1. Effect of Dietary Regimen on Abdominal Fat $(\mathrm{g} / \mathrm{kg})$ of the Four Strains at $1200-1300 \mathrm{~g}$ (Female) and 1300-1400 g (Males) 
Table 3. Body Weight (g), Growth Rate (g/d) and Rearing Period (d) of the Four Commercial Strains at Target Body Weight* of Four Commercial Strains at different feeding regimen

\begin{tabular}{|c|c|c|c|c|c|c|c|c|}
\hline \multirow[b]{2}{*}{ Strain } & \multirow[b]{2}{*}{ Diet } & \multicolumn{4}{|c|}{ Male } & \multicolumn{3}{|c|}{ Female } \\
\hline & & \multicolumn{2}{|c|}{ Body Weight } & \multirow[t]{2}{*}{ Growth Rate } & \multirow[t]{2}{*}{ Age at Termination** } & \multicolumn{2}{|c|}{ Body Weight } & \multirow[t]{2}{*}{ Growth Rate } \\
\hline & & Starter & Finisher & & & Starter & Finisher & \\
\hline \multirow[t]{4}{*}{ A } & SS & $666 \pm 28$ & $1322 \pm 12$ & $49.2 \pm 4.4$ & $30.2 \pm 3.2$ & $619 \pm 24$ & $1208 \pm 31$ & $49.1 \pm 3.0$ \\
\hline & SF & $675 \pm 16$ & $1350 \pm 84$ & $30.4 \pm 4.0$ & $39.0 \pm 2.9$ & $611 \pm 11$ & $1217 \pm 55$ & $36.2 \pm 4.3$ \\
\hline & FS & $687 \pm 39$ & $1384 \pm 33$ & $61.7 \pm 6.3$ & $37.0 \pm 0.8$ & $622 \pm 0.7$ & $1303 \pm 65$ & $62.0 \pm 1.9$ \\
\hline & FF & $679 \pm 15$ & $1338 \pm 28$ & $51.5 \pm 4.2$ & $37.8 \pm 0.9$ & $634 \pm 62$ & $1240 \pm 32$ & $43.0 \pm 7.9$ \\
\hline \multirow[t]{4}{*}{$\mathrm{B}$} & SS & $663 \pm 25$ & $1306 \pm 23$ & $48.0 \pm 3.5$ & $32.6 \pm 2.6$ & $600 \pm 10$ & $1307 \pm 24$ & $47.1 \pm 9.7$ \\
\hline & SF & $653 \pm 41$ & $1326 \pm 15$ & $36.9 \pm 3.7$ & $36.2 \pm 3.2$ & $622 \pm 23$ & $1326 \pm 15$ & $37.3 \pm 6.3$ \\
\hline & FS & $691 \pm 68$ & $1360 \pm 41$ & $64.3 \pm 14.3$ & $37.2 \pm 4.0$ & $612 \pm 16$ & $1360 \pm 41$ & $58.6 \pm 7.0$ \\
\hline & $\mathrm{FF}$ & $701 \pm 35$ & $1330 \pm 26$ & $47.4 \pm 8.7$ & $37.8 \pm 1.9$ & $655 \pm 34$ & $1330 \pm 26$ & $43.2 \pm 3.5$ \\
\hline \multirow[t]{4}{*}{$\mathrm{C}$} & SS & $650 \pm 14$ & $1312 \pm 27$ & $53.5 \pm 9.0$ & $28.2 \pm 2.0$ & $627 \pm 24$ & $1259 \pm 24$ & $49.8 \pm 5.6$ \\
\hline & SF & $671 \pm 22$ & $1331 \pm 27$ & $37.9 \pm 6.7$ & $33.8 \pm 3.3$ & $635 \pm 24$ & $1241 \pm 70$ & $34.3 \pm 3.3$ \\
\hline & FS & $657 \pm 22$ & $1359 \pm 47$ & $68.0 \pm 7.9$ & $36.0 \pm 3.7$ & $668 \pm 48$ & $1268 \pm 68$ & $63.1 \pm 4.0$ \\
\hline & FF & $707 \pm 36$ & $1354 \pm 27$ & $46.8 \pm 2.9$ & $39.5 \pm 2.1$ & $635 \pm 27$ & $1277 \pm 51$ & $34.1 \pm 1.7$ \\
\hline \multirow[t]{4}{*}{$\mathrm{D}$} & SS & $661 \pm 29$ & $1367 \pm 59$ & $59.1 \pm 3.8$ & $29.3 \pm 2.8$ & $636 \pm 31$ & $1243 \pm 64$ & $50.8 \pm 4.1$ \\
\hline & SF & $651 \pm 15$ & $1390 \pm 24$ & $38.0 \pm 0.5$ & $36.7 \pm 0.5$ & $625 \pm 7.0$ & $1237 \pm 49$ & $35.0 \pm 3.8$ \\
\hline & FS & $685 \pm 30$ & $1355 \pm 36$ & $65.1 \pm 11.8$ & $36.6 \pm 1.1$ & $611 \pm 31$ & $1310 \pm 64$ & $56.9 \pm 2.9$ \\
\hline & FF & $683 \pm 28$ & $1367 \pm 53$ & $45.4 \pm 4.2$ & $41.7 \pm 1.8$ & $652 \pm 52$ & $1241 \pm 60$ & $42.2 \pm 2.3$ \\
\hline
\end{tabular}

* Target Body Weight = approximately 600-650 g (during starter) and 1200-1300 g (during finisher) for females; Target body weight approximately 650-700 g (during starter) and 1300-1400 g (during finisher) for males;

** Age termination $=$ age at slaughtering when birds on target body weight

$\mathrm{A}=$ Steggels; $\mathrm{B}=\mathrm{Cobb} ; \mathrm{C}=$ Ingham; $\mathrm{D}=$ Barter

$\mathrm{SF}=$ Starter-Finisher $; \mathrm{FS}=$ Finisher-Starter; SS = Starter-Starter; FF $=$ Finisher-Finisher

birds came into production and had some influence on carcass fleshing traits (Renema et al., 2006).

This is in agreement with results of Barragán (2005) who suggested that fat deposition could be reduced significantly by feeding the starter diet for a greater proportion of the growing period. Nutrition can significantly affect fat-free body composition at a certain fat-free body weight in modern meat-type animals (Eits et al., 2002) and profile amino acids can affect on weight gain and feed conversion (Koch et al., 2002; Araújo et al., 2004) as well as carcass protein and fat deposition (Furlan et al., 2004).

The considerably greater relative propensity for Ingham in comparison with Cobb, Steggels and Barter to deposit fat in response to a reduction in dietary protein during the starter phase, would appear to be reflective of differences in selection approaches. It is significant that Ingham had been selected on feed efficiency which was shown by the low body fatness on the higher protein starter diet but moderate to high fatness on the low protein finisher diet (Table 2 and 4). Selection for low FCR whilst improving the net efficiency of utilisation of protein (Tomas et al., 1988) also increases the dietary protein requirement for growth and FCR (Leenstra and Pym, 1995; Pym, 2005). Other consequences of this selection were response to inadequate dietary protein in this genotype is to increase the deposition of body fat. No direct relationship between weight gain and fat deposition was evident (Table 2).

Griffiths et al. (1978) reported on considerable variation in the amount of abdominal fat deposited by commercial broiler strains at 4 and $8 \mathrm{wk}$ of age. The accumulation of fat at $4 \mathrm{wk}$ was primarily due to genetic variation whereas beyond this age, variation in abdominal fat was due principally to dietary effects. Whilst genetic factors had a major effect on body fatness at the conclusion of the starter and grower phases in the present study, the effect of diet was much greater at the earlier age. This is in agreement with Barragán (2005) who prolonged feeding starter or finisher feeds in broilers.

This study clearly demonstrates that the effect genotype do exist, and birds with low 
Table 4. The Influence of Four Dietary Regimens on Growth Rate (g/d), during the Grower and Combined Starter and Grower Phase and FCR and Abdominal Fat $(\mathrm{g} / \mathrm{kg})$ of the Four Commercial Strains during the Grower Phase

\begin{tabular}{|c|c|c|c|c|}
\hline \multirow{2}{*}{ Variable } & \multicolumn{2}{|c|}{ Growth rate } & \multirow{2}{*}{ FCR } & \multirow{2}{*}{ Abdominal Fat } \\
\hline & Grower & Combined S + G1 & & \\
\hline \multicolumn{5}{|l|}{ Sex } \\
\hline Male & $38.6^{\mathrm{a}}$ & $42.0^{\mathrm{a}}$ & 1.95 & $10.6^{\mathrm{b}}$ \\
\hline Female & $36.2^{\mathrm{b}}$ & $39.6^{\mathrm{b}}$ & 1.99 & $14.2^{\mathrm{a}}$ \\
\hline LSD 0.05 & 1.4 & 1.25 & 0.09 & 1.47 \\
\hline \multicolumn{5}{|l|}{ Strain } \\
\hline Steggels & 52.2 & 36.1 & $1.965^{\mathrm{ab}}$ & $12.76^{\mathrm{b}}$ \\
\hline Cobb & 52.8 & 35.4 & $1.936^{\mathrm{b}}$ & $15.14^{\mathrm{a}}$ \\
\hline Ingham & 54.4 & 37.5 & $1.904 \mathrm{~b}$ & $9.33^{\mathrm{c}}$ \\
\hline Barter & 52 & 35.3 & $1.977^{\mathrm{ab}}$ & $13.84^{\mathrm{ab}}$ \\
\hline LSD 0.05 & 2.4 & 3.4 & 0.16 & 2.180 \\
\hline \multicolumn{5}{|c|}{ Dietary regimen } \\
\hline $\mathrm{SF}$ & $36.2 d$ & $33.7^{\mathrm{c}}$ & $2.540^{\mathrm{a}}$ & $9.59^{\mathrm{c}}$ \\
\hline SS & $53.8^{\mathrm{b}}$ & $40.3^{\mathrm{a}}$ & $1.701 \mathrm{c}$ & $7.87^{\mathrm{c}}$ \\
\hline FS & $67.9^{\mathrm{a}}$ & $35.0^{\mathrm{b}}$ & $1.474 \mathrm{~d}$ & $15.27^{\mathrm{b}}$ \\
\hline $\mathrm{FF}$ & $48.3^{\mathrm{c}}$ & $31.7 \mathrm{~d}$ & $2.098^{\mathrm{b}}$ & $17.81^{\mathrm{a}}$ \\
\hline LSD 0.05 & 2 & 1 & 0.14 & 2.53 \\
\hline \multicolumn{5}{|l|}{ Source } \\
\hline Sex & $* *$ & $* *$ & NS & $* *$ \\
\hline Strain & NS & NS & $* *$ & $* *$ \\
\hline Diet & $* *$ & $* *$ & $* *$ & $* *$ \\
\hline \multicolumn{5}{|l|}{ Interaction } \\
\hline Strain x Diet & $*$ & NS & NS & NS \\
\hline Strain x Sex & NS & NS & NS & NS \\
\hline Sex x Diet & NS & NS & NS & NS \\
\hline
\end{tabular}

a-d: Values within comparison with different superscripts is differ $((\mathrm{P}<0.05)$

$\mathrm{S}=$ Starter; $\mathrm{G}=$ Grower; 1 Combined $\mathrm{S}+\mathrm{G}=$ Starter and Grower phase (5 d to $1250-1350 \mathrm{~g}$ )

$\mathrm{SF}=$ Starter-Finisher; FS = Finisher-Starter; $\mathrm{SS}=$ Starter-Starter; FF $=$ Finisher-Finisher

$*(\mathrm{P}<0.05) ; * *(\mathrm{P}<0.01 ; \quad \mathrm{NS}=$ Not Significant $(\mathrm{P}>0.05)$

\section{CONCLUSION}

performance which indicated by high FCR and high abdominal fat during the growing observed in all genotypes showed insufficient supply of amino acids as required. In other words, birds tend to response in similar way when dealing with the excesses and insufficient supply. Therefore, the nutrient requirements dealing with the protein: energy ratios should be designed according to genetic background. And a standard feeding regimen that commonly applied in broiler production should also be revaluated and modified.
The results obtained in this study allow concluding that the genetic lines do have differences in performance. Birds tend to response in similar way when dealing with the excesses and insufficient supply. The nutrient requirements dealing with the protein: energy ratios should be designed according to genetic background. The accumulation of fat during the growing period was primarily due to genetic variation whereas beyond this age, variation in abdominal fat was due principally to dietary effects. Protein and energy ratios significantly effects on growth performance and abdominal fat, depending on the 
production performance when a diet was introduced.

\section{ACKNOWLEDGMENT}

The authors are grateful to support of Mr. John Hayer for his able technical assistance. My particular thank to my best friend, Sutan Dillak, Borris Popovic and Kurt van Velthuizen for their valuable assistance with data collection.

\section{REFERENCES}

Agriculture Research Council. 1975. The nutrient requirements of farm livestock. No. 1 Poultry, 2 edition. HMSO, London.

Araújo, L.F., O.M. Junqueira, C.S.S.Araújo, D.E.Faria and M.O. Andreotti. 2004. Different criteria of feed formulation for broilers aged 43 to 49 days. Brazilian J. of Poult. Sci. 6(1): 61-64

Baker, D.H. 2004. Animal models of human amino acid responses. J. Nutr. 134: 1646S$1650 \mathrm{~S}$

Barragán, J.I. 2005. Optimization of nutritional programs for meat-type. Changing paradigms in poultry nutrition and management chickens. Proceeding of the Symposium March 9-10, 2005 Madeira, Portugal. p. 52-57

Corzo, A., M.T. Kidd, D.J. Burnham, E.R. Miller, S.L. Branton and R. Gonzalez-Esquerra. 2005. Dietary amino acid density effects on growth and carcass of broilers differing in strain cross and sex. J. Appl. Poult. Res. 14:1-9

Eits, R.M., R.P. Kwakkel and M.W.A. Verstegen. 2002. Nutrition affects fat-free body composition in broiler chickens. J. Nutr. 132: 2222-2228.

Furlan, R.L, Faria Filho DE de, R.S. Rosa and M. Macari. 2004. Does low-protein diet improve broiler performance under heat stress conditions? Brazilian J. Poult. Sci., 6 (2): $71-79$

Gous, R.M., G.C. Emmans, L.A. Broadbent and C. Fisher. 1990. Nutritional effects on growth and fatness of broilers. Br. Poult. Sci. 31:495-505.

Griffiths, L., S. Leeson and J.D. Summers. 1978. Studies on abdominal fat with four commercial strains of male broiler chickens. Poult. Sci. 57:1198-1203.

Jórgensen, H., P. Sórensen and B.O. Eggum.
1990. Protein and energy metabolism in broiler chickens selected for either body weight gain or feed efficiency. Br. Poult. Sci. 31:517-524.

Kaps, M and W. Lamberson. 2004. Biostatistics for Animal Science. CABI Publishing, Wallingford,UK

Koch F., J.A.P. Wijtten, L. Andreas and D.J. Langhout. 2002. Impact of a balanced amino acid profile on broiler performance. Veterianrija ir zootechnika, 19(41):70-75

Leclercq, B. 1983. The influence of dietary protein content on the performance of genetically lean or fat growing chickens. Br. Poult. Sci. 24: 581-587.

Leenstra, F.R. and R.A.E. Pym. 1995. Genetic lines in broiler research. Archiv für Geflügel-Kunde. Supplement:3-6.

Morel, P.C.H., H. Schaeublin, D.V, Thomas and V. Ravindran. 2002. Protein deposition potential in broiler chickens. Conf. Proc. of 12 th Austr.Poult. and Feed Convention. 610 October Gold Coast -Queensland Australia. Pages 46-47.

National Research Council. 1987. Predicting feed intake of food-producing Animals. National Academy Press, Washington, D.C.

National Research Council. 1994. Nutrient Requirements of Poultry. Ninth Revised Edition. National Academy Press, Washington, D.C.

Pym, R.A.E. 2005. Genetic aspects of food intake and food utilization efficiency for growth in chickens. Aust. Poult. Sci. Symp. 17 : 153162

Pym. R.A.E. and D.J. Farrell.1977. A comparison of the energy and nitrogen metabolism of broilers selected for increased growth rate, food consumption and conversion of food to protein. Br. Poult. Sci. 18: 411-426.

Rahimi, G and M. Hassanzadeh. 2007. Effects of different protein and energy contents of the diet on growth performance and hormonal parameters in two commercial broiler strains. Intern. J of Poult. Sci. 6 (3): 195200

Renema, R.A., F.E. Robinson and M.J. Zuidhof . 2006. Role of broiler breeder genetics on breeder chick quality and sensitivity to overfeeding. Aust. Poult. Sci. Symp. 18 : 34-38

Sadeghi, G.H. and S.A. Tabiedian. 2005. Effect of different energy to protein ratio and tallow supplementation on broiler 
performance. Intern. J. of Poult. Sci. 4 (12): 976-981.

Saleh, E.A., S.E. Watkins and P.W. Waldroup. 1997a. Changing time of feeding starter, grower, and finisher diets for broilers 2 . Birds grown to $2.2 \mathrm{~kg}$. J. Appl. Poult. Res. 6: 64-73.

Saleh, E.A., S.E. Watkins and P.W. Waldroup. 1997b. Changing time of feeding starter, grower, and finisher diets for broilers 3. Birds grown to $3.3 \mathrm{~kg}$. J. Appl. Poult. Res. 6:290-297.

Smith, M.O. 1993. Parts yield of broilers reared under cycling high temperatures. Poult. Sci. 72 (10):1207-14.

Smith, E.R., G.M. Pesti, R.I. Bakalli, G.O. Ware and J.F.M. Menten .1998. Further studies on the influence of genotype and dietary protein on the performance of broilers. Poult. Sci. 77: 1678-1687.

Sizemore, F.G. and H.S. Siegel. 1993. Growth, feed conversion, and carcass composition in females of four broiler crosses fed starter diets with different energy levels and energy to protein ratios. Poult. Sci. 72: 2216-2228

Sterling, K.G., G.M. Pesti and R.I. Bakalli. 2003. Performance of broiler chicks fed various levels of dietary lysine and crude protein. Poult. Sci. 82: 1939-1947

Sterling, K.G., G.M. Pesti and R.I. Bakalli. 2006. Performance of different broiler genotypes fed diets with varying levels of dietary crude protein and lysine. Poult. Sci. 85: 1045-1054

Summers, J.D., D. Spratt and J.L. Atkinson. 1992. Broiler weight gain and carcass composition when fed diets varying in amino acid balance, dietary energy, and protein level. Poult. Sci. 71: 263-273.

Swatson, H.K., R.Gous, P.A.Iji and R. Zarrinkalam. 2002. Effect of dietary protein level, amino acid balance and feeding level on growth, gastrointestinal tract, and mucosal structure of the small intestine in broiler chickens. Anim. Res. 51 (2002) 501515. INRA, EDP Sciences, 2002; DOI: 10.1051/animres:2002038

Tomas, F.M., L.M. Jones and R.A.E. Pym. 1988. Rates of muscle protein breakdown in chickens selected for increased growth rate, food consumption or efficiency of food utilisation as assessed by $\mathrm{N}^{\lambda}$-methylhistidine excretion. Br. Poult. Sci. 29:359-370.

Vieira, S.L., A. Lemme, D.B. Goldenberg and I. Brugalli. 2004. Response of growing broilers to diets with increased sulfur amino acids to lysine ratios at two dietary protein levels. Poult. Sci. 83:1307-1313

Washburn, K.W., R.A. Guill, and H.M. Jr. Edwards. 1975. Influence of genetic differences in feed efficiency on carcass composition of young chickens. J. Nutr.105:1311-1317. 